\title{
Hepatitis C Recurrence after Orthotopic Liver Transplantation: Mechanisms and Management
}

\author{
Bobby Kakati ${ }^{1}$ and Anil Seetharam*1,2 \\ ${ }^{1}$ Banner Transplant and Advanced Liver Disease Center, Phoenix, AZ, USA; ${ }^{2}$ University of Arizona College of Medicine-Phoenix, \\ Phoenix, AZ, USA
}

\begin{abstract}
Chronic Hepatitis C (HCV) infection is the leading indication for orthotopic liver transplantation and recurrence is nearly universal. Chronic HCV infection is frequently established through evasion of the innate immune system. Priming of adaptive immune responses modulate the severity and rate of fibrosis progression. Those with demonstrable viremia entering the transplant period uniformly suffer recurrence post-transplant. Progression to cirrhosis is accelerated posttransplant secondary to systemic immunosuppression. In addition, a number of factors, including donor, host, and viral characteristics, influence severity and rate of fibrosis progression. Interferon-based therapy, the previous standard of care, in those with advanced cirrhosis or post-transplant has been limited by a number of issues. These include a relative lack of efficacy and poor tolerability with higher incidence of infection and anemia. Recently, approval of direct acting antivirals have ushered in a new era in HCV therapeutics and have applicability in these special populations. Their use immediately prior to or post-transplant is expected to improve both morbidity and mortality.

(C) 2014 The Second Affiliated Hospital of Chongqing Medical University. Published by XIA \& HE Publishing Ltd. All rights reserved.
\end{abstract}

\section{Introduction}

Chronic hepatitis $\mathrm{C}(\mathrm{HCV})$ infection is a major public health problem; with an estimated 180 million people infected worldwide and approximately 4 million infected in the

Keywords: Innate immunity; Fibrogenesis; Sofosbuvir; Simeprevir. Abbreviations: AASLD, American Association for Liver Disease; ALT, alanine aminotransferase; CMV, cytomegalovirus; CsA, cyclosporine; CTP, Child Turcotte Pugh; CUPIC, compassionate use of protease inhibitors in viral C cirrhosis; DAA, direct acting antiviral; DCD, donation after cardiac death; DDLT, deceased donor liver transplantation; FCH, fibrosing cholestatic hepatitis; FDA, Food and Drug Administration; HCC, hepatocellular carcinoma; HCV, hepatitis C virus; HHV, human herpes virus; IDSA, Infectious Disease Society of America; IGD, immunemediated graft dysfunction; IL, interleukin; ISG, interferon stimulated gene; LADR, low accelerated dose regimen; LDLT, liver donor liver transplantation MELD, model for end-stage liver disease; NS, non-structural; Peg-IFN, pegylated interferon; PTVR, post-transplant virologic response; RBV, ribavirin; RNA, ribonucleic acid; SNP, single nucleotide polymorphism; SVR, sustained virologic response; Tac, tacrolimus; Th, T-helper; Treg, t-regulatory; US, United States. Received: 14 May 2014; Revised: 06 June 2014; Accepted: 07 July 2014 DOI: $10.14218 / \mathrm{JCTH} .2014 .00016$.

*Correspondence to: Anil Seetharam, University of Arizona College of MedicinePhoenix, Banner Transplant and Advanced Liver Disease Center, Phoenix, AZ 85006, USA. Tel: +1-602-839-7000, Fax: +1-602-839-7050, E-mail: Anil. Seetharam@bannerhealth.com
United States (US). ${ }^{1}$ For approximately two decades, therapy has been relatively expensive and difficult to complete. More recently, direct acting antivirals (DAAs) have been developed and are revolutionizing treatment paradigms. ${ }^{2}$ Their timely application prior to the development of cirrhosis is projected to lessen the incidence of end stage liver disease (and associated complications) attributable to chronic HCV infection. In addition, their use is expected to improve outcomes after orthotopic liver transplantation.

\section{Transplantation for hepatitis $\mathbf{C}$ virus}

$\mathrm{HCV}$ infection is currently the leading indication for orthotopic liver transplantation, and it is estimated that approximately one-third of patients on the waiting list for transplant are infected. ${ }^{3}$ Although the incidence of new infection with progression to cirrhosis may be declining, there has been a concomitant rise in transplant listing for hepatocellular carcinoma (HCC) related to HCV cirrhosis. ${ }^{4}$

While graft and patient survival rates have steadily improved for non-HCV related indications, this is not true for HCV related transplants. ${ }^{5}$ For over a decade, relatively poorer results have been noted for those with $\mathrm{HCV}$ indications. ${ }^{6}$ In a recent review of the Organ Procurement Transplant Network/ United Network of Organ sharing (OPTN/UNOS), 3 year survival was at $78 \%$ for 7,459 anti-HCV positive recipients and $82 \%$ for 20,734 anti-HCV negative recipients. ${ }^{7}$ Similar results were reported in Europe: $73 \%$ survival in non-HCV recipients compared with only $66 \%$ in HCV positive recipients. ${ }^{8}$ Significant interest has focused on reasons for this discrepancy in outcomes with HCV. In this context, systemic immunosuppression and advancing donor age appear to be important. ${ }^{9,10}$ The phenomenon of HCV recurrence after transplant is the driving force for these poorer outcomes. ${ }^{11}$

\section{HCV reinfection}

Reinfection of liver allografts is considered universal and occurs at the time of allograft reperfusion. ${ }^{12,13}$ During the anhepatic phase of transplant surgery, HCV ribonucleic acid (RNA) levels decline to undetectable levels, but after only a few hours, increase rapidly to peak by the fourth postoperative month. ${ }^{14}$ At 1 year, HCV RNA levels are generally 1 to 2 logs higher than prior to liver transplant. ${ }^{15}$ The diagnosis of recurrent HCV infection requires detection of HCV RNA in serum; and the diagnosis of recurrent disease requires compatible histology as well. Histologic features of liver injury will typically develop after 3 months and resemble those seen in the native liver. ${ }^{16}$ Once re-infection is established, the 
Kakati B. et al: HCV recurrence after orthotopic liver transplantation

disease progresses; and $20 \%$ to $54 \%$ of liver transplant recipients develop bridging fibrosis-cirrhosis within 5 years post-transplantation. ${ }^{17}$ Persistent low level inflammation and loss of viral control mechanisms from systemic immunosuppression account for this accelerated progression of cirrhosis. In addition, co-factors, such as diabetes mellitus (preexisting or promoted by use of calcineurin based immunosuppression), may further promote disease progression. Accelerated progression post-transplant is variable; dependent upon the degree of immunosuppression and a number of patient cofactors and baseline demographics. Variability in the aforementioned manifests through multiple clinical variations of recurrence: ranging from standard "run of the mill" HCV recurrence to the highly lethal, e.g. fibrosing cholestatic hepatitis $(\mathrm{FCH})$.

\section{Clinical presentations of HCV recurrence}

\section{"Standard" HCV recurrence}

Transition from acute hepatitis to chronic hepatitis usually occurs between 3 and 9 months after transplantation. Transplant recipients may develop histologic features of acute hepatitis $\mathrm{C}$ accompanied by a rapid rise in HCV viral load. The most common pattern of recurrence is the evolution over time to chronic hepatitis, as it occurs in immunocompetent patients (albeit at higher levels of viremia and faster progression of fibrosis). Fibrosis can progress linearly, but its course is variable and often unpredictable. ${ }^{18}$ Interestingly, a non-Markov analysis based on 901 fibrosis measurements in 401 patients showed that risk of progression decreases as time in a given stage increases. ${ }^{19}$ However, a longer time to reach a stage does not predict a lower risk of progressing to a higher stage. Serial biopsies in patients with recurrent hepatitis $C$ have demonstrated annual rates of fibrosis progression between 0.3 and 0.6 stages/year (score F0-F4) versus 0.1 to 0.2 stages/year in immunocompetent patients with chronic hepatitis $C^{20-22}$ The median interval from transplantation to cirrhosis is 9.5 years versus 30 years from infection until cirrhosis in immunocompetent patients. The best predictor of cirrhosis risk at 5 years is severity of necroinflammatory activity in the allograft at 12 months posttransplant. ${ }^{23}$ Often, protocol biopsies are performed by transplant programs to monitor fibrosis progression.

\section{Fibrosing cholestatic hepatitis}

$\mathrm{FCH}$ is a presentation of HCV largely unique to liver allograft recipients and often occurs within the first year after transplantation. $\mathrm{FCH}$ can be present in over-immunosuppressed recipients, and studies typically show homogeneous viral quasispecies and massive HCV RNA levels in the peripheral circulation (usually $>30-50$ million $\mathrm{IU} / \mathrm{mL}$ ). ${ }^{24}$ Liver damage in $\mathrm{FCH}$ is due to a direct viral cytopathic effect on hepatocytes from massive HCV replication. ${ }^{25}$ The typical case of $\mathrm{FCH} \mathrm{HCV}$ is characterized by extensive hepatocyte swelling necrosis, cholestasis, and Kupffer cell hypertrophy in combination with portal expansion due to prominent ductular reaction (often with absent or rare Cytokeratin-7+ intermediate cells) and fibrotic-type interface activity with mild mixed or even neutrophil-predominant portal inflammation. ${ }^{26}$ The intrahepatic immune response in FCH HCV is typically T-helper (Th)2-like; whereas it is Th-1-predominant in conventional recurrent $\mathrm{HCV}$, and the few infiltrating lymphocytes often lack
HCV specificity. ${ }^{27}$ Apart from immunosuppression, clear risk factors with regard to genotype and patient demographics have not been well established. FCH usually leads to liver failure/ graft loss within 1 to 2 years after transplantation.

\section{Autoimmune HCV recurrence}

Recurrent chronic HCV can present with plasma cell-rich, interface necroinflammatory activity resembling autoimmune hepatitis. ${ }^{28}$ Determining whether this presentation represents an "autoimmune" variant of $\mathrm{HCV}$, acute cellular rejection, de novo autoimmune hepatitis, or a combination is often very difficult and requires extensive history and evaluation. This recurrence variant is often recognized during the transition from acute hepatitis to chronic hepatitis or after the onset of chronic hepatitis. Typical histologic findings include "sheets of plasma cells" at the sites of severe interface and/or perivenular necroinflammatory activity. ${ }^{29}$ In clinical scenarios where histology is highly consistent with autoimmune hepatitis, immunosuppressive therapy can be used to abrogate the severity of liver damage. However, such therapies may enhance HCV replication and promote HCV specific induced inflammation and fibrosis progression.

\section{Factors affecting recurrence}

Multiple factors are thought to affect HCV recurrence after liver transplant. These can be organized as traits of the host (recipient of new liver) or donor (transplanted liver) and viral factors. ${ }^{23}$

\section{Host factors}

\section{Gender}

An epidemiologic study in the non-transplant setting demonstrated that females exhibit a slower rate of fibrosis progression per year and a lower overall incidence of end-stage liver disease than men. ${ }^{30}$ Studies suggested a possible antifibrogenic effect of estrogen on hepatic stellate cells and less rapid progression pre-transplant. ${ }^{31,32}$ The situation appears to be different post-transplant; however, as one multicenter study of more than $500 \mathrm{HCV}$-positive recipients found the risk of severe hepatitis $C$ recurrence following transplantation from a donor older than 60 years was doubled in female recipients compared to males. ${ }^{33}$ Higher rates of graft loss and advanced fibrosis in women have been corroborated by a more recent study. ${ }^{34}$

\section{Host immune responses}

Strong multispecific CD4+ and CD8+ T-cell responses are associated with spontaneous clearance and successful antiviral therapy during the course of $\mathrm{HCV}$ infection in the native liver-signifying their importance in abrogation of inflammation/fibrosis progression. The blunting of these seemingly protective adaptive immune responses by immunosuppression may actually contribute to the universal reinfection and accelerated disease progression observed after transplantation. ${ }^{35}$ Detection of vigorous multispecific CD4+ T-cell responses in the early post-transplant period may predict mild graft injury and a greater response to antiviral therapy. The presence of strong innate immune responses (natural killer $\mathrm{T}$ cells) prior to transplantation may also 
provide protection from severe graft injury following liver transplantation. ${ }^{36}$

In addition to the aforementioned risks, older age, African American ethnicity, presence of metabolic syndrome, and coinfection with HIV have been associated with worse outcomes. ${ }^{37,38}$ It is speculated that these co-factors likely modulate the natural history of recurrence and are well established negative predictors of response to interferon based antiviral therapy. ${ }^{39}$

\section{Donor issues}

\section{Donor/transplant surgery-related issues}

Multiple donor-related issues affect the outcome of hepatitis $C$ infection in the post-transplant setting. Worldwide, the shortage of organs has led to an increasing use of "extended criteria donors." Such donor grafts of reduced quality may be more sensitive to damaging events such as ischemia/ reperfusion injury and recurrent hepatitis $C .{ }^{40}$

\section{Age and donation after cardiac death}

In liver recipients with $\mathrm{HCV}$, older donor age has emerged as an important factor influencing disease recurrence and progression. ${ }^{41}$ The mean age of donors has increased over the last several years. ${ }^{42}$ Donation after cardiac death (DCD) liver transplantation is associated with worse patient and graft survival than donation after brain death liver transplantation, with increased incidence of biliary and vascular complications in HCV recipients, especially with older donors. ${ }^{43-45}$

\section{Steatosis}

The role of donor steatosis and recurrence in HCV patients is controversial. Fibrosis evolution appears to be higher when graft steatosis is over $30 \%,{ }^{46}$ and steatosis over $30-45 \%$ in the donor liver is often avoided when HCV is the transplant indication. ${ }^{47}$ Apart from sensitivity to ischemia/reperfusion injury and HCV induced inflammation, there may be an influence of steatosis on adaptive immune responses. ${ }^{48}$

\section{Cold ischemia time}

Recently implemented "Share 35" protocols have increased regional sharing of liver allografts that in turn may increase cold ischemia times. Recipients of livers from donors aged 45 years or older and cold ischemia times more than 12 hours showed increased risk of graft failure compared with recipients of livers from donors younger than 45 years and cold ischemia less than 12 hours. ${ }^{49}$

\section{Live donor transplantation}

Living donor liver transplantation (LDLT) is a rapidly evolving field with expanding utilization in the face of significant organ shortage. The Adult-to-Adult Live Donor Liver Transplant Cohort Study found that graft survival in HCV-positive LDLT recipients (once there was sufficient LDLT experience at a given center) was similar to that of deceased donor liver transplant (DDLT) recipients. ${ }^{50}$ Additionally, studies using protocol liver biopsies to assess disease severity found no significant difference in the rate of fibrosis progression between recipients of LDLT and DDLT within a 5 year followup periods. ${ }^{51}$

\section{Donor/host IL28B}

Genome-wide studies have demonstrated a strong association between allelic variations in the Interleukin-28 (IL28B) gene and response to HCV therapy with interferon. The precise mechanism through which the IL28B single nucleotide polymorphism (SNP) genotype influences response to antiviral treatment has not been fully characterized. IFNlambda 3, the product of the IL28B gene, belongs to the type III interferon family and induces interferon-stimulated genes (ISGs), differentiation of dendritic cells, modulation of Th1 and Th2 immune responses, and inhibition of T-regulatory (Treg) cells that serve as a critical link between innate and adaptive immune responses to viral infection. ${ }^{52}$ In a recent study, recipients with a CC genotype (favorable response to interferon based antiviral therapy) have relatively slower histologic recurrence, with decreased alanine aminotransferase (ALT) levels and viral load when compared with non-CC genotypes. The opposite association is seen with donor CC genotype. ${ }^{53}$

\section{Viral factors}

\section{Viral load and genotype}

Higher HCV RNA levels in both serum and liver at the time of transplantation are linked with increased risk of progression to cirrhosis, graft loss, and death. ${ }^{35}$ There is some controversy regarding the relationship between viral genotype and severity of recurrence, as genotype $1 \mathrm{~b}$ has been associated with more severe recurrent hepatitis $C$ in some patient series but not in others. ${ }^{54,55}$

\section{Viral genomic heterogeneity (Quasispecies)}

Quasispecies diversity increases with the duration of chronic $\mathrm{HCV}$ infection and may be most robust in end-stage liver disease. Following liver transplantation, diversity falls during the early period of intense immunosuppression and remains low in those cases with rapidly progressive cholestatic hepatitis $C^{56}$ Diversity frequently increases in those who develop mild chronic hepatitis, reflecting increased selective pressure during maintenance immunosuppression. ${ }^{57}$

\section{Concomitant virus post transplant}

Both cytomegalovirus (CMV) and human herpesvirus 6 (HHV 6 ) infection have been associated with increased progression of fibrosis during HCV reinfection after liver transplantation. ${ }^{58}$ These relationships highlight the importance of CMV prophylaxis in transplant populations. ${ }^{59}$

\section{Peri-transplant management of HCV}

\section{Historical perspective}

The goal of any effective antiviral therapy is eradication with minimal side effects. Historically, previous standard of care treatment with pegylated interferon (Peg-IFN) and ribavirin (RBV) contributed to a number of side effects and was largely ineffective with sustained virologic response (SVR) rates 
Kakati B. et al: HCV recurrence after orthotopic liver transplantation

varying from $7-30 \%$ in HCV genotype 1 patients and $44-50 \%$ in non 1 genotypes. ${ }^{60}$ Major predictors of achieving SVR included: low pretreatment viral load, Child Turcotte Pugh (CTP) score class A (genotype 1 only), and completion of treatment. ${ }^{61}$ These early studies highlighted the risk of decompensation with interferon based therapy in those with advanced fibrosis and a particularly high risk for infection. ${ }^{62}$ Despite the significant incidence of adverse effects and relative lack of efficacy, attempts at treatment were made in an effort to "deliver the patient aviremic" to transplant to lessen the chance of recurrence post-operatively. Investigators further evaluated the strategy of a low accelerating dose regimen (LADR) in populations with advanced fibrosis prior to transplant to prevent recurrence. ${ }^{63}$ Treatment using a LADR was initiated with Peg-IFN-alpha-2b $(0.75 \mu \mathrm{g} /$ $\mathrm{kg} /$ week) and RBV (600 mg/day). Dose escalations were then performed at weeks one (Peg-IFN 1.5 microg/kg/week and RBV $800 \mathrm{mg} /$ day), two (RBV $1.0 \mathrm{~g} /$ day), and three (RBV $1.2 \mathrm{~g} /$ day for patients weighing greater than $75 \mathrm{~kg}$ ) based on tolerance, side effects, and weekly serum labs. Pre-transplant treatment prevented post-transplant recurrence of $\mathrm{HCV}$ infection in $25 \%$ of transplanted cases- $22 \%$ in HCV genotypes $1 / 4 / 6$ and $29 \%$ in HCV genotypes $2 / 3$. The strongest predictor of post-transplant virologic response ( $p T V R$ ) was duration of treatment prior to transplant; however, Peg-IFN and RBV were poorly tolerated with an increase in serious adverse events (cytopenias, infection, and hepatic decompensation) in the LADR treated cohort.

\section{Directing acting antivirals pre-transplant}

With the introduction of first generation direct acting antivirals telaprevir and boceprevir (NS3/4A protease inhibitors) in 2011, much interest focused upon their applicability in treatment experienced populations with advanced fibrosis. However, phase III studies did not include a large number of cirrhotics. ${ }^{64,65}$ Recently, results from the Compassionate Use of Protease Inhibitors in Viral C Cirrhosis (CUPIC) cohort evaluating the effectiveness of first generation protease inhibitor with Peg-IFN and RBV in treatment experienced HCV genotype 1 patients with cirrhosis were reported. ${ }^{66}$ In 511 patients who did not respond to a prior course of Peg-IFN and RBV, telaprevir $(n=299)$ or boceprevir $(n=212)$ was used for 48 weeks. Among the telaprevir treated cohort, $74.2 \%$ of previous relapsers, $40.0 \%$ of partial responders, and $19.4 \%$ of null responders achieved SVR12. Among the boceprevir cohort, $53.9 \%$ of relapsers, $38.3 \%$ of partial responders, and none of the null responders achieved SVR12. While efficacy was certainly improved with addition of a first generation protease inhibitor, issues of tolerability remained. Severe adverse events occurred in $49.9 \%$ of cases, including liver decompensation and death in $2.2 \%$. On multivariate analysis, baseline parameters, including prior null response and serum albumin level $<35 \mathrm{~g} / \mathrm{L}$, and platelet count $\leqslant 100,000$ ), predicted serious adverse events and use was cautioned in patients with these factors.

Towards the end of 2013, two additional agents were added to the HCV armamentarium: simeprevir, a second generation once daily NS3/4A inhibitor, and sofusbuvir, an NS5B polymerase inhibitor of HCV. ${ }^{67,68}$ Clinical studies that led to Food and Drug Administration (FDA) approval for sofosbuvir demonstrated relatively high efficacy and safety in patients with cirrhosis. ${ }^{69}$ Both agents are approved as agents in combination with either Peg-IFN or RBV. As previously mentioned, there has been a rise in transplant listings for HCC related to HCV cirrhosis, and HCC may develop in those with well compensated cirrhosis (i.e., low native Model for EndStage Liver Disease (MELD). Such a patient population with relatively well compensated cirrhosis listed for orthotopic liver transplant by virtue of concomitant HCC represented an excellent opportunity to evaluate second generation DAA efficacy prior to transplant in preventing post-transplant recurrence. Curry et al. recently reported results from a Phase 2, open-label study investigating use of sofosbuvir plus RBV for up to 48 weeks in patients with HCV listed for liver transplant with $\mathrm{HCC}^{70}$ Patients with chronic HCV infection of any genotype listed for liver transplantation for $\mathrm{HCC}$ received up to 48 weeks of sofosbuvir ( $400 \mathrm{mg} /$ day) and RBV (1000$1200 \mathrm{mg} /$ day) before transplantation. Overall, sofosbuvir and RBV therapy was safe with well compensated cirrhosis and prevented post-transplant $\mathrm{HCV}$ recurrence in $64 \%$ of patients who had HCV RNA $<25 \mathrm{IU} / \mathrm{mL}$ prior to transplant. The number of consecutive days with HCV RNA target not detected prior to transplant appeared to be the strongest predictor of post-transplant HCV recurrence. Certainly, as new agents are developed, their applicability will be tested in cirrhotic populations to further optimize efficacy and minimize serious adverse events (Table 1 ).

\section{Treatment of recurrence post-transplant}

Given the difficulty in treating cirrhotic populations prior to transplant, much attention has focused on treatment posttransplant. In this context, two approaches have been examined: 1) a pre-emptive approach where antiviral therapy is used in the first weeks following transplantation and 2) a histologic, recurrence-based approach for patients with established hepatitis. Early post transplantation therapy administered during the first 2-7 weeks post-transplantation before there is clinical evidence of liver damage has been evaluated. ${ }^{71}$ The results have been disappointing overall in terms of antiviral efficacy and tolerability. With PegIFN based therapy, SVR rates of about $20 \%$ have been documented, ranging from 18 to $39 \%$ (5-33\% in genotype 1 and $14-100 \%$ in genotypes 2/3). ${ }^{71}$ About $30 \%$ of patients discontinue treatment, and dose reductions are required in $70 \%$ secondary to side effects, such as bacterial infections, hematological toxicity, and rejections $(0-26 \%) .^{72}$

The most widely used strategy involves the initiation of antiviral therapy once histologic consequences of $\mathrm{HCV}$ recurrence are detected on allograft biopsy. With PEG-IFN and RBV, the previous standard of care, studies estimate SVR at a rate of $30 \% .{ }^{73,74}$ Transplanted patients were particularly predisposed to hematologic toxicities, especially anemia $(60-80 \%)$, necessitating careful and frequent RBV dose adjustments.

In addition, patients with recurrent HCV infection treated with Peg-IFN (PEG) after liver transplantation can develop severe immune-mediated graft dysfunction (IGD) characterized by plasma cell hepatitis or rejection. A recent multicenter case-control study of 52 liver transplant recipients with hepatitis $C$ assessed the incidence of, risk factors for, and outcomes of PEG-IGD. ${ }^{75}$ Overall incidence of PEG-IGD during a 10 -year study period was $7.2 \%$. Variables associated with increased mortality included acute rejection as the PEG-IGD sub-type and lack of a SVR. Variables associated with graft failure included a high level of alkaline phosphatase at PEG initiation and lack of a SVR. 
Kakati B. et al: HCV recurrence after orthotopic liver transplantation

Table 1. Summary of Treatment Trials Pre-Transplant: Recent studies have evaluated the effectiveness of pegylated interferon (Peg-IFN) and ribavirin (RBV) in conjunction with newer direct acting antiviral agents including: sofosbuvir (SOF), simeprevir (SMV) and ledipasvir (LED). Identification of increasingly tolerable regimens prior to transplant able to achieve high SVR12 or reliable post transplant virologic response (pTVR) are in development.

\begin{tabular}{|c|c|c|c|c|c|}
\hline Study & Agents & $\begin{array}{l}\text { Patients } \\
\text { (n) }\end{array}$ & $\begin{array}{l}\text { Virologic response (\%) } \\
\text { (SVR 12/pTVR) }\end{array}$ & $\begin{array}{l}\text { Adverse } \\
\text { events (\%) }\end{array}$ & $\begin{array}{l}\text { Influential } \\
\text { predictors }\end{array}$ \\
\hline $\begin{array}{l}\text { Everson et al., } \\
2013\end{array}$ & $\begin{array}{l}\text { Peg-IFN alfa2b } \\
\text { \& RBV (with } \\
\text { dose escalation) }\end{array}$ & 59 & $\begin{array}{l}22 \% \text { GT } 1 \\
29 \% \text { GT } 2 / 3\end{array}$ & 68-Serious & $\begin{array}{l}\text { Duration of treat- } \\
\text { ment }>16 \text { weeks }\end{array}$ \\
\hline $\begin{array}{l}\text { Hezode et al., }{ }^{66} \\
2014\end{array}$ & $\begin{array}{l}\text { Peg-IFN alfa 2b } \\
\text { \& RBV with } \\
\text { Telaprevir or } \\
\text { Boceprevir }\end{array}$ & $\begin{array}{l}511 \\
\text { 299-Telaprevir } \\
\text { 212-Boceprevir }\end{array}$ & $\begin{array}{l}\text { SVR12/Agent/Previous history } \\
\text { Telaprevir } \\
\text { 74.2/relapsers } \\
\text { 40/partial responders } \\
\text { 19.4/null responders } \\
\text { Boceprevir } \\
\text { 53.9/relapsers } \\
\text { 38.3/partial responders } \\
\text { 0/null responders }\end{array}$ & 49.9-Serious & $\begin{array}{l}\text { Response to prior } \\
\text { therapy } \\
\text { Albumin }<35 \mathrm{~g} / \mathrm{L} \\
\text { Plts }<100,000\end{array}$ \\
\hline $\begin{array}{l}\text { Curry et al., } \\
2013\end{array}$ & $\begin{array}{l}\text { Sofosbuvir \& } \\
\text { RBV }\end{array}$ & 61 & $64 \%$ & 18-Serious & $\begin{array}{l}\text { Number of days } \\
\text { with HCV RNA } \\
\text { below lower limit } \\
\text { of detection }\end{array}$ \\
\hline $\begin{array}{l}\text { Lawitz et al., }{ }^{84} \\
2014\end{array}$ & $\begin{array}{l}\text { Simeprevir \& } \\
\text { Sofosbuvir }+/- \\
\text { RBV }\end{array}$ & 87 & $\begin{array}{l}\text { SVR12/Duration/Agent } \\
\text { 93/12 weeks/SOF + SMV } \\
93 / 12 \text { weeks/SOF + SMV + RBV } \\
\text { 100/24 weeks SOF + SMV } \\
\text { 93/24 weeks/SOF +SMV + RBV }\end{array}$ & 4.6-Serious & $\begin{array}{l}\text { ? Q80K poly- } \\
\text { morphism }\end{array}$ \\
\hline $\begin{array}{l}\text { Afdahl et al., } \\
2014\end{array}$ & $\begin{array}{l}\text { Ledipasvir \& } \\
\text { Sofosbuvir } \\
+ \text { /- RBV }\end{array}$ & $\begin{array}{l}440 \text { total trea- } \\
\text { ted } \\
\text { ( } 88 \text { Cirrhotic) }\end{array}$ & $\begin{array}{l}\text { SVR12/Duration/Agent } \\
86 / 12 \text { weeks/SOF + LED } \\
\text { 82/12 weeks/SOF + LED + RBV } \\
\text { 99/24 weeks SOF + LED } \\
\text { 99/24 weeks/SOF + LED + RBV }\end{array}$ & $\begin{array}{l}0 \text {-Serious } \\
67-90 \% \text { mild to } \\
\text { moderate } \\
\text { depending on } \\
\text { regimen/duration }\end{array}$ & $\begin{array}{l}\text { ? NS5A resis- } \\
\text { tance at baseline }\end{array}$ \\
\hline
\end{tabular}

\section{Directing antivirals post-transplant}

Interferon based therapy post-transplantation is fraught with a number of issues, including: comparative lack of efficacy, infection, anemia, and immune mediated graft dysfunction. However, similar to the case of their applicability immediately prior to transplant, much interest has focused on their efficacy in treatment of recurrence. A major limitation with first generation DAAs (telaprevir and boceprevir) are interactions with calcineurin inhibitors cyclosporine (CsA) and tacrolimus (Tac), the cornerstones of immunosuppression post liver transplant. Boceprevir and telaprevir are potent inhibitors of cytochrome P450 3A4. In a study of healthy volunteers, boceprevir was shown to increase the area under the curve of CsA and Tac by 2.7 and of 17 , respectively. ${ }^{76}$ In another study, the concomitant administration of a calcinuerin inhibitor with telaprevir in healthy volunteers increased CsA and Tac exposures approximately 4.6-fold and 70 -fold, respectively. ${ }^{77}$

Recently, interim results from Europe evaluating the efficacy of telaprevir in conjunction with Peg-IFN and RBV post-transplant have been presented. ${ }^{78}$ Patients receiving calcineurin based immunosuppression ( 6 months to 10 years after LT), with fibrosis stage F0-F3, received telaprevir, PegIFN, and RBV for 12 weeks and Peg-IFN and RBV for an additional 36 weeks. The study included 74 post-transplant patients, and at week $12,40(80 \%)$ patients on tacrolimus and $21(87.5 \%)$ on cyclosporine achieved undetectable HCV RNA. Common adverse events included anemia, pruritus, and rash. These results show improved efficacy with first generation DAAs and, importantly, manageable levels of immunosuppression with close monitoring.

A US based retrospective cohort study of 81 patients with genotype $1 \mathrm{HCV}$ treated with boceprevir (10\%) or telaprevir (90\%) plus Peg-IFN and RBV was performed with SVR12 as the primary endpoint. ${ }^{79}$ The intent-to-treat SVR12 rate was $63 \%$ in this post-transplant cohort. Patients with extended rapid virologic response (undetectable HCV RNA at 4 and 12 weeks after starting boceprevir or telaprevir) had higher rates of SVR12 compared to all other patients ( $85 \%$ vs. $15 \%)$. Similar to the European study, adverse effects were common; $21 \%$ of patients experienced hemoglobin $<8 \mathrm{~g} / \mathrm{dL}$, and $57 \%$ required blood transfusions during the first 16 weeks. Twenty seven percent were hospitalized, and $9 \%$ died.

In another investigation of 37 liver recipients with advanced HCV recurrence (either $\geqslant F 2$ fibrosis $[n=31$ ] or fibrosing cholestatic hepatitis $[\mathrm{n}=6]$ ) treated with Peg-IFN, RBV, and first generation DAA, SVR12 was observed in $20 \%$ $(1 / 5)$ and $71 \%(5 / 7)$ of patients in telaprevir and boceprevir groups, respectively $(p=0.24) .{ }^{80}$ Treatment was discontinued in 16 patients (treatment failures $(n=11)$, serious adverse events $(n=5))$.

Emerging data with second generation DAAs shows promise in the post-transplant population regarding efficacy and tolerability. Preliminary results presented at AASLD 2013 showed that in a population of transplant recipients with HCV recurrence (predominately genotype 1 ) treated with sofosbuvir (400 mg daily) along with RBV (400 mg daily) with dose 
Kakati B. et al: HCV recurrence after orthotopic liver transplantation

escalation based on hemoglobin, $77 \%$ of patients achieved SVR 4 and all patients demonstrated HCV RNA below the lower limit of detection 4 weeks after treatment. ${ }^{81}$ Treatment was well tolerated and no interactions with immunosuppressive agents were observed. In addition, recent data from the sofosbuvir compassionate use program for patients with severe recurrent hepatitis $\mathrm{C}$, including fibrosing cholestatic hepatitis following liver transplantation, showed higher rates of SVR12 $(62 \%)$ than standard therapies in this context, improved liver function tests, and improved clinical outcomes $^{82}$ (Table 2).

Recently, the use of sofosbuvir and simeprevir in combination has been examined. ${ }^{83}$ At EASL 2014: Cohort 2 of the COSMOS trial consisting of those with advanced fibrosis (F3F4) showed overall SVR rates of over $90 \%$ with a 12 week regimen not containing RBV. ${ }^{84}$ Phase III clinical studies evaluating the combination of sofosbuvir and simeprevir are currently underway.

In the upcoming months, further regimens will be added to the HCV armamentarium. It is expected that newer approved regimens with agents such as ledipasvir (NS5A inhibitor) will have sufficient data to make recommendations for usage in those with cirrhosis and possibly on the road to liver transplant. ${ }^{85}$ In addition, studies for the aforementioned agents are being conducted in post-transplant populations. In another recent study of a regimen containing ABT-450/r/ABT-267 along with ABT-333 and RBV in liver transplant recipients with genotype 1 recurrence, $96 \%$ of patients achieved an SVR12 with 24 weeks of therapy. ${ }^{86}$ An unprecedented number of treatment regimens are on the horizon.

The American Association for Liver Diseases (AASLD) and Infectious Disease Society of America (IDSA) have published recommendations regarding treatment of $\mathrm{HCV}$ recurrence in the allograft. ${ }^{87}$ Here is a new recommended treatment option for treatment naïve patients with genotype 1 recurrence in the allograft includes: sofosbuvir $(400 \mathrm{mg})$ plus simeprevir $(150 \mathrm{mg}$ ), with or without RBV (initial dose $600 \mathrm{mg} /$ day, increased monthly by $200 \mathrm{mg} /$ day as tolerated to weight-based dose of $1,000 \mathrm{mg}[<75 \mathrm{~kg}$ ] to $1200 \mathrm{mg}$ $[>75 \mathrm{~kg}])$, for 12 weeks to 24 weeks. Another alternate regimen for treatment naïve patients with genotype $1 \mathrm{HCV}$ in the allograft liver, including those with compensated cirrhosis, is as follows: sofosbuvir (400 mg) and RBV (initial dose $600 \mathrm{mg} /$ day, increased monthly by $200 \mathrm{mg} /$ day as tolerated to weight-based dose of $1000 \mathrm{mg}[<75 \mathrm{~kg}]$ to $1200 \mathrm{mg}$ $[>75 \mathrm{~kg}]$ ) with or without Peg-IFN (in the absence of contraindication to its use), for 24 weeks in patients with compensated allograft HCV genotype 1 infection. A recommended regimen for treatment-naïve patients with HCV genotype 2 or 3 in the allograft liver, including those with compensated cirrhosis, is as follows: sofosbuvir (400 mg) and RBV (initial dose $600 \mathrm{mg} /$ day, increased monthly by $200 \mathrm{mg} /$ day as tolerated to weight-based dosages) with consideration of the patient's creatinine clearance value and hemoglobin level for 24 weeks. These guidelines are dynamic and are expected to be revised as new agents become approved and clinical experience grows.

\section{Conclusions}

Chronic Hepatitis C remains the leading indication for liver transplantation, and recurrence post-transplantation is universal for those who enter the transplant period with viremia. Recurrence is characterized by an accelerated progression to fibrosis that is thought to be related to loss of viral control in the context of systemic immunosuppression. A number of donor, host, and viral characteristics influence the clinical manifestations of recurrence. Previous standard of care therapy with Peg-IFN in end-stage liver disease was limited by decompensation, infection, and post-transplant by anemia. Newer additions to the direct acting antiviral armamentarium have been introduced with increasing applicability in cirrhotic and post-transplant populations. Their timely use prior to transplant is expected to improve outcomes posttransplant; and their use post-transplant is expected to improve morbidity and mortality.

Table 2. Summary of Treatment Trials Post-Transplant: Recent studies have evaluated the effectiveness of pegylated interferon (Peg-IFN) and ribavirin (RBV) in conjunction with newer direct acting antiviral agents including post-transplant

\begin{tabular}{|c|c|c|c|c|}
\hline Study & Agents & $\begin{array}{l}\text { Patients } \\
\text { (n) }\end{array}$ & $\begin{array}{l}\text { SVR } 12 \\
\text { (\%) ( } \mathrm{n} \text { where } \\
\text { applicable) }\end{array}$ & Adverse events \\
\hline $\begin{array}{l}\text { Forns et al., }{ }^{78} 2014 \\
\text { (interim analysis) }\end{array}$ & $\begin{array}{l}\text { Peg-IFN alfa } 2 b \text { \& } \\
\text { RBV \& Telaprevir }\end{array}$ & 74 & $59.6 \%(19 / 32)$ & $\begin{array}{l}11 \% \text {-serious } \\
60 \% \text {-anemia }\end{array}$ \\
\hline Burton et al., ${ }^{79} 2014$ & $\begin{array}{l}\text { Peg-IFN alfa } 2 b \text { \& } \\
\text { RBV \& Telaprevir or } \\
\text { Boceprevir }\end{array}$ & $\begin{array}{l}81 \\
\text { (10\% boceprevir/ } \\
90 \% \text { telaprevir) }\end{array}$ & $63 \%$ & $\begin{array}{l}\text { Common } \\
21 \% \mathrm{Hgb}<8 \mathrm{~g} / \mathrm{dL} \\
57 \% \text { requiring transfusions } \\
9 \% \text { liver related death }\end{array}$ \\
\hline Coilly et al., 802014 & $\begin{array}{l}\text { Peg-IFN alfa } 2 \text { b \& } \\
\text { RBV \& Telaprevir or } \\
\text { Boceprevir }\end{array}$ & $\begin{array}{l}37 \\
\text { Boceprevir }(n=18) \\
\text { Telaprevir }(n=19\end{array}$ & $\begin{array}{l}71 \%(5 / 7) \\
\text { Boceprevir } \\
20 \%(1 / 5) \text { Telaprevir }\end{array}$ & $\begin{array}{l}\text { Common } \\
16 \text { discontinuations } \\
92 \% \text {-anemia }\end{array}$ \\
\hline $\begin{array}{l}\text { Charlton et al., }{ }^{81} 2013 \\
\text { (abstract) }\end{array}$ & Sofosbuvir \& RBV & 40 & SVR $4-77 \%$ & $15 \%$-serious \\
\hline $\begin{array}{l}\text { Forns et al., }{ }^{82} 2014 \\
\text { (abstract) }\end{array}$ & Sofosbuvir \& RBV & 104 & $62 \%$ & $48 \%$-serious \\
\hline $\begin{array}{l}\text { Kwo et al., }{ }^{86} 2014 \\
\text { (abstract) }\end{array}$ & $\begin{array}{l}\text { ABT-450/r/ABT-267 + } \\
\text { ABT-333 + Ribavirin }\end{array}$ & 34 & $96.2 \%$ & $\begin{array}{l}5.8 \% \text {-serious } \\
17.6 \% \text {-anemia }\end{array}$ \\
\hline
\end{tabular}




\section{Conflict of interest}

Dr. Seetharam reports the following: speaker's bureau: Merck, Gilead; advisory boards: Janssen, Gilead.

\section{Author contributions}

Writing the review (BK, AS).

\section{References}

[1] Barretto N, Sainz B Jr, Hussain S, Uprichard SL. Determining the involvement and therapeutic implications of host cellular factors in hepatitis $\mathrm{C}$ virus cellto-cell spread. J Virol 2014;9:5050-5061. doi: 10.1128/JVI.03241-13.

[2] Pawlotsky JM. New hepatitis C virus (HCV) drugs and the hope for a cure: concepts in anti-HCV drug development. Semin Liver Dis 2014;34:22-29. doi: $10.1055 / \mathrm{s}-0034-1371007$.

[3] Burton JR Jr, Everson GT. Management of the transplant recipient with chronic hepatitis C. Clin Liver Dis 2013;17:73-91. doi: 10.1016/j.cld.2012.09.013.

[4] Chan SC. Liver transplantation for hepatocellular carcinoma. Liver Cancer 2013;2:338-344. doi: 10.1159/000343849.

[5] Dhanasekaran R, Firpi RJ. Challenges of recurrent hepatitis $C$ in the liver transplant patient. World J Gastroenterol 2014;20:3391-3400.

[6] Forman LM, Lewis JD, Berlin JA, Feldman HI, Lucey MR. The association between hepatitis $C$ infection and survival after orthotopic liver transplantation. Gastroenterology 2002;122:889-896. doi: 10.1053/gast.2002.32418.

[7] www.unos.org, accessed January 2014.

[8] http://www.eltr.org, accessed January 2014.

[9] Coilly A, Roche B, Samuel D. Current management and perspectives for HCV recurrence after liver transplantation. Liver Int 2013;33 (Suppl 1):56-62. doi: $10.1111 /$ liv.12062.

[10] Mutimer DJ, Gunson B, Chen J, Berenguer J, Neuhaus P, Castaing D, et al. Impact of donor age and year of transplantation on graft and patient survival following liver transplantation for hepatitis C virus. Transplantation 2006;81: 7-14. doi: 10.1097/01.tp.0000188619.30677.84.

[11] Hsu SH, Yeh ML, Wang SN. New insights in recurrent HCV infection after liver transplantation. Clin Dev Immunol 2013;2013:890517. doi: 10.1155/2013/ 890517.

[12] Gane EJ, Naoumov NV, Qian KP, Mondelli MU, Maertens G, Portmann BC, et al. A longitudinal analysis of hepatitis $C$ virus replication following liver transplantation. Gastroenterology 1996;110:167-177. doi: 10.1053/ gast.1996.v110.pm8536853.

[13] Garcia-Retortillo M, Forns X, Feliu A, Moitinho E, Costa J, Navasa M, et al. Hepatitis $C$ virus kinetics during and immediately after liver transplantation. Hepatology 2002;35:680-687. doi: 10.1053/jhep.2002.31773.

[14] Ballardini G, De Raffele E, Groff P, Bioulac-Sage P, Grassi A, Ghetti S, et al. Timing of reinfection and mechanisms of hepatocellular damage in transplanted hepatitis C virus-reinfected liver. Liver Transpl 2002;8:10-20. doi: $10.1053 /$ jlts.2002.30141.

[15] Sreekumar R, Gonzalez-Koch A, Maor-Kendler $Y$, Batts K, Moreno-Luna L, Poterucha J, et al. Early identification of recipients with progressive histologic recurrence of hepatitis C after liver transplantation. Hepatology 2000;32: 1125-1130. doi: 10.1053/jhep.2000.19340.

[16] Rodriguez-Luna $\mathrm{H}$, Vargas HE. Management of hepatitis $\mathrm{C}$ virus infection in the setting of liver transplantation. Liver Transpl 2005;11:479-489. doi: $10.1002 /$ It. 20424

[17] Berenguer M, Schuppan D. Progression of liver fibrosis in post-transplant hepatitis C: mechanisms, assessment and treatment. J Hepatol 2013;58: 1028-1041. doi: 10.1016/j.jhep.2012.12.014.

[18] Roche B, Sebagh M, Canfora ML, Antonini T, Roque-Afonso AM, Delvart $V_{\text {, }}$ et al. Hepatitis $C$ virus therapy in liver transplant recipients: response predictors, effect on fibrosis progression, and importance of the initial stage of fibrosis. Liver Transpl 2008;14:1766-1777. doi: 10.1002/It.21635.

[19] Bacchetti P, Boylan RD, Terrault N, Monto A, Berenguer M. Non-Markov multistate modelling using time-varying covariates, with application to progression of liver fibrosis due to hepatitis $C$ following liver transplantation. Int J Biostatistics 2010;6: Article 7. doi: 10.2202/1557-4679.1213

[20] Berenguer M, Ferrell L, Watson J, Prieto M, Kim M, Rayón M, et al. HCV related fibrosis progression following liver transplantation: increase in recent years. J Hepatol 2000;32:673-684. doi: 10.1016/S0168-8278(00)80231-7.

[21] Firpi RJ, Abdelmalek MF, Soldevila-Pico C, Cabrera R, Shuster J], Theriaque $D$, et al. One-year protocol liver biopsy can stratify fibrosis progression in liver transplant recipients with recurrent hepatitis C infection. Liver Transp 2004;10:1240-1247. doi: 10.1002/It.20238.

[22] Poynard T, Bedossa P, Opolon P. Natural history of liver fibrosis progression in patients with chronic hepatitis C. The OBSVIRC, METAVIR, CLINIVIR, and
DOSVIRC groups. Lancet 1997;349:825-832. doi: 10.1016/S01406736(96)07642-8.

[23] Berenguer M. Host and donor risk factors before and after liver transplantation that impact HCV recurrence. Liver Transpl 2003;9:S44-47. doi: $10.1053 /$ jlts.2003.50243.

[24] Cimsit B, Assis D, Caldwell C, Arvelakis A, Taddei T, Kulkarni S, et al. Successful treatment of fibrosing cholestatic hepatitis after liver transplantation. Transplant Proc 2011:43:905-908, doi: 10.1016/j.transproceed 2011.02.034.

[25] Rosenberg PM, Farrell J], Abraczinskas DR, Graeme-Cook FM, Dienstag JL, Chung RT. Rapidly progressive fibrosing cholestatic hepatitis-hepatitis C virus in HIV coinfection. Am J Gastroenterol 2002;97:478-483. doi: 10.1111/j.1572-0241.2002.05459.x.

[26] Salomao M, Verna EC, Lefkowitch JH, Moreira RK. Histopathologic distinction between fibrosing cholestatic hepatitis $C$ and biliary obstruction. Am J Surg Pathol 2013;37:1837-1844. doi: 10.1097/PAS.0b013e31829b626c.

[27] Zekry A, Bishop GA, Bowen DG, Gleeson MM, Guney S, Painter DM, et al. Intrahepatic cytokine profiles associated with posttransplantation hepatitis $C$ virus-related liver injury. Liver Transpl 2002;8:292-301. doi: 10.1053/ jlts.2002.31655.

[28] Ward SC, Schiano TD, Thung SN, Fiel MI. Plasma cell hepatitis in hepatitis C virus patients post-liver transplantation: case-control study showing poor outcome and predictive features in the liver explant. Liver Transpl 2009;15 1826-1833. doi: 10.1002/It.21949.

[29] Kallwitz ER. Recurrent hepatitis $C$ virus after transplant and the importance of plasma cells on biopsy. World J Gastroenterol 2013;19:158-160.

[30] Marcellin P, Asselah T, Boyer N. Fibrosis and disease progression in hepatitis C. Hepatology 2002;36:S47-56. doi: 10.1002/hep.1840360707.

[31] Shimizu I. Impact of oestrogens on the progression of liver disease. Liver Int 2003;23:63-69. doi: 10.1034/j.1600-0676.2003.00811.x.

[32] Di Martino V, Lebray P, Myers RP, Pannier E, Paradis V, Charlotte F, et al. Progression of liver fibrosis in women infected with hepatitis C: long-term benefit of estrogen exposure. Hepatology 2004;40:1426-1433. doi: 10.1002/ hep. 20463.

[33] Belli LS, Burroughs AK, Burra P, Alberti AB, Samonakis D, Cammà C, et al. Liver transplantation for HCV cirrhosis: improved survival in recent years and increased severity of recurrent disease in female recipients: results of a long term retrospective study. Liver Transpl 2007;13:733-740. doi: 10.1002/It.21093.

[34] Lai JC, Verna EC, Brown RS Jr, O'Leary JG, Trotter JF, Forman LM, et al. Hepatitis $\mathrm{C}$ virus-infected women have a higher risk of advanced fibrosis and graft loss after liver transplantation than men. Hepatology 2011;54:418424. doi: $10.1002 /$ hep. 24390

[35] Gane EJ. The natural history of recurrent hepatitis $C$ and what influences this. Liver Transpl 2008;14 (Suppl 2):S36-44. doi: 10.1002/It.21646.

[36] Rosen HR, Doherty DG, Madrigal-Estebas L, O'Farrelly C, Golden-Mason L. Pretransplantation CD56+ innate lymphocyte populations associated with severity of HCV recurrence. Liver Transpl 2008;14:31-40. doi: 10.1002/It.21265.

[37] Layden JE, Cotler S, Brown KA, Lucey MR, Te HS, Eswaran S, et al. Racia differences in fibrosis progression after HCV-related liver transplantation. Transplantation 2012;94:178-184. doi: 10.1097/TP.0b013e318253f7fa.

[38] Congly SE, Doucette KE, Coffin CS. Outcomes and management of vira hepatitis and human immunodeficiency virus co-infection in liver transplantation. World J Gastroenterol 2014;20:414-424. doi: 10.3748/wjg.v20.i2.414.

[39] Patton HM, Patel K, Behling C, Bylund D, Blatt LM, Vallée M, et al. The impact of steatosis on disease progression and early and sustained treatment response in chronic hepatitis C patients. J Hepatol 2004;40:484-490. doi: 10.1016/j.jhep.2003.11.004.

[40] Durand F, Renz JF, Alkofer B, Burra P, Clavien PA, Porte RJ, et al. Report of the Paris consensus meeting on expanded criteria donors in liver transplantation. Liver Transpl 2008;14:1694-1707. doi: 10.1002/It.21668.

[41] Lake JR, Shorr JS, Steffen B], Chu AH, Gordon RD, Wiesner RH. Differentia effects of donor age in liver transplant recipients infected with hepatitis $B$ hepatitis C and without viral hepatitis. Am J Transplant 2005;5:549-557. doi: $10.1111 / \mathrm{j} .1600-6143.2005 .00741 . x$.

[42] Sela N, Croome KP, Chandok N, Marotta P, Wall W, Hernandez-Alejandro R. Changing donor characteristics in liver transplantation over the last 10 years in canada. Liver Transpl 2013;19:1236-1244. doi: 10.1002/It.23718.

[43] Uemura T, Ramprasad V, Hollenbeak CS, Bezinover D, Kadry Z. Liver transplantation for hepatitis $\mathrm{C}$ from donation after cardiac death donors: an analysis of OPTN/UNOS data. Am J Transplant 2012;12:984-991. doi: 10.1111/j.1600-6143.2011.03899.x.

[44] Taner CB, Bulatao IG, Keaveny AP, Willingham DL, Pungpapong S, Perry DK, et al. Use of liver grafts from donation after cardiac death donors for recipients with hepatitis C virus. Liver tranpl 2011:17:641-649. doi: 10.1002/It.22258.

[45] Tao R, Ruppert K, Cruz RJ Jr, Malik SM, Shaikh O, Ahmad J, et al. Hepatitis C recurrence is not adversely affected by the use of donation after cardiac death liver allografts. Liver Transpl 2010;16:1288-1295. doi: 10.1002/It.22168.

[46] De Martin E, Senzolo M, Gambato M, Germani G, Vitale A, Russo FR, et al. Fibrosis progression and the pros and cons of antiviral therapy for hepatitis $C$ virus recurrence after liver transplantation: a review. Transplant Proc 2010 42:2223-2225. doi: 10.1016/j.transproceed.2010.05.035. 
[47] Ciria R, Pleguezuelo M, Khorsandi SE, Davila D, Suddle A, Vilca-Melendez H, et al. Strategies to reduce hepatitis $C$ virus recurrence after liver transplantation. World J Hepatol 2013;5:237-250. doi: 10.4254/wjh.v5.i5.237.

[48] Subramanian V, Seetharam AB, Vachharajani N, Tiriveedhi V, Angaswamy N, Ramachandran $\mathrm{S}$, et al. Donor graft steatosis influences immunity to hepatitis $\mathrm{C}$ virus and allograft outcome after liver transplantation. Transplantation 2011;92:1259-1268. doi: 10.1097/TP.0b013e318235a1ab.

[49] Gambato M, Frigo AC, Rodríguez Castro KI, Senzolo M, Nadal E, D'Amico F, et al. Who fares worse after liver transplantation? Impact of donor and recipient variables on outcome: data from a prospective study. Transplantation 2013;95:1528-1534. doi: 10.1097/TP.0b013e318292827f.

[50] Terrault NA, Shiffman ML, Lok AS, Saab S, Tong L, Brown RS Jr, et al. Outcomes in hepatitis $C$ virus-infected recipients of living donor vs. deceased donor liver transplantation. Liver Transpl 2007;13:122-129. doi: 10.1002/It.20995.

[51] Olthoff KM, Abecassis MM, Emond JC, Kam I, Merion RM, Gillespie BW, et al. Outcomes of adult living donor liver transplantation: comparison of the Adultto-adult Living Donor Liver Transplantation Cohort Study and the national experience. Liver Transpl 2011;17:789-797. doi: 10.1002/It.22288.

[52] Hayes CN, Imamura M, Aikata H, Chayama K. Genetics of IL28B and HCVresponse to infection and treatment. Nat Rev Gastroenterol Hepatol 2012;9: 406-417. doi: 10.1038/nrgastro.2012.101.

[53] Duarte-Rojo A, Veldt B], Goldstein DD, Tillman HL, Watt KD, Heimbach JK, et al. The course of posttransplant hepatitis $C$ infection: comparative impact of donor and recipient source of the favorable IL28B genotype and other variables. Transplantation 2012;94:197-203. doi: 10.1097/TP.0b013e3182547551.

[54] Villa E, Groffola A, Buttafoco P, Merighi A, Ferretti I, Trande P, et al. Long-term follow-up of hepatitis $\mathrm{C}$ virus ( $\mathrm{HCV}$ ) infection in liver transplant patients. Clin Transplant 1995;9:160-164.

[55] Gayowski T, Singh N, Marino I, Vargas H, Wagener M, Wannstedt C, et al. HCV genotypes in liver transplant recipients: Impact on Posttransplant Recurrence, Infections, Response to Interferon- $\alpha$ Therapy and Outcome. Transplantation 1997;64:422-426. doi: 10.1097/00007890-199708150-00009.

[56] Pessoa MG, Bzowej N, Berenguer M, Phung Y, Kim M, Ferrell L, et al. Evolution of hepatitis $C$ virus quasispecies in patients with severe cholestatic hepatitis after liver transplantation. Hepatology 1999;30:1513-1520. doi: 10.1002/ hep. 510300610.

[57] Doughty AL, Zekry A, Spencer JD, Turhan S, Painter D, McCaughan GW. Spontaneous clearance of hepatitis $C$ virus infection post-liver transplantation is associated with rapidly changing quasispecies: a single case report. Liver Transpl 2000;6:648-653. doi: 10.1053/jits.2000.9740.

[58] Humar A, Kumar D, Raboud J, Caliendo AM, Moussa G, Levy G, et al. Interactions between CMV, HHV-6 and recurrence of $\mathrm{HCV}$ after liver transplantation. Am J Transplant 2002;2:461-466. doi: 10.1034/j.16006143.2002.20511.x.

[59] Bosch W, Heckman MG, Pungpapong S, Diehl NN, Shalev JA, Hellinger WC. Association of cytomegalovirus infection and disease with recurrent hepatitis C after liver transplantation. Transplantation 2012;93:723-728. doi: 10.1097/TP.0b013e3182472876.

[60] Everson GT, Trotter J, Forman L, Kugelmas M, Halprin A, Fey B, et al. Treatment of advanced hepatitis $C$ with a low accelerating dosage regimen of antiviral therapy. Hepatology 2005;42:255-262. doi: 10.1002/hep.20793.

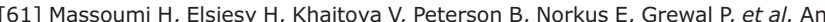
escalating dose regimen of pegylated interferon and ribavirin in HCV cirrhotic patients referred for liver transplant. Transplantation 2009;88:729-735. doi: 10.1097/TP.0b013e3181b2e0d1.

[62] Carrion JA, Martinez-Bauer E, Crespo G, Ramirez S, Perez-del-Pulgar S, GarciaValdecasas JC, et al. Antiviral therapy increases the risk of bacterial infections in $\mathrm{HCV}$-infected cirrhotic patients awaiting liver transplantation: a retrospective study. J Hepatol 2009;50:719-728. doi: 10.1016/j.jhep.2008.11.015.

[63] Everson GT, Terrault NR, Lok AS, Rodrigo del R, Brown RS Jr, Saab S, et al. A randomized controlled trial of pretransplant antiviral therapy to prevent recurrence of hepatitis C after liver transplantation. Hepatology 2013;57: 1752-1762. doi: 10.1002/hep.25976.

[64] Zeuzem S, Andreone P, Pol S, Lawitz E, Diago M, Roberts S, et al. Telaprevir for retreatment of HCV infection. N Engl J Med 2011;364:2417-2428. doi: 10.1056/NEJMoa1013086.

[65] Bacon BR, Gordon SC, Lawitz E, Marcellin P, Vierling JM, Zeuzem S, et al. Boceprevir for previously treated chronic HCV genotype 1 infection. N Engl J Med 2011;364:1207-1217. doi: 10.1056/NEJMoa1009482.

[66] Hézode C, Fontaine H, Dorival C, Zoulim F, Larrey D, Canva V, et al. Effectiveness of telaprevir or boceprevir in treatment-experienced patients with HCV genotype 1 infection and cirrhosis. Gastroenterology 2014;147: 132-142. doi: 10.1053/j.gastro.2014.03.051.

[67] Fried MW, Buti M, Dore G], Flisiak R, Ferenci P, Jacobson I, et al. Once-daily simeprevir (TMC435) with pegylated interferon and ribavirin in treatmentnaïve genotype 1 hepatitis C: the randomized PILLAR study. Hepatology 2013;58:1918-1929. doi: 10.1002/hep.26641.
[68] Lawitz E, Mangia A, Wyles D, Rodriguez-Torres M, Hassanein T, Gordon SC, et al. Sofosbuvir for previously untreated chronic hepatitis $C$ infection. N Engl J Med 2013;368:1878-1887. doi: 10.1056/NEJMoa1214853.

[69] Jacobson IM, Gordon SC, Kowdley KV, Yoshida EM, Rodriguez-Torres M, Sulkowski MS, et al. Sofosbuvir for hepatitis C genotype 2 or 3 in patients without treatment options. N Engl J Med 2013;368:1867-1877. doi: 10.1056/NEJMoa1214854.

[70] Curry M, Forns X, Chung R, Terrault N, Brown R Jr, Fenkel J, et al. Pretransplant Sofosbuvir and Ribavirin to Prevent Recurrence of $\mathrm{HCV}$ Infection after Liver Transplantation. 64th Annual Meeting of the American Association for the Study of Liver diseases, November 1-5, 2013, Washington, USA; abstract 213.

[71] Terrault NA. Prophylactic and preemptive therapies for hepatitis C virusinfected patients undergoing liver transplantation. Liver Transplant 2003;9: S95-100. doi: 10.1053/jlts.2003.50255.

[72] Bzowej N, Nelson DR, Terrault NA, Everson GT, Teng LL, Prabhakar A, et al PHOENIX: a randomized controlled trial of peginterferon alfa-2a plus ribavirin as a prophylactic treatment after liver transplantation for hepatitis $C$ virus. Liver Transplant 2011;17:528-538. doi: 10.1002/It.22271.

[73] Xirouchakis E, Triantos C, Manousou P, Sigalas A, Calvaruso V, Corbani A, et al. Pegylated-interferon and ribavirin in liver transplant candidates and recipients with HCV cirrhosis: systematic review and meta-analysis of prospective controlled studies. J Viral Hepat 2008;15:699-709. doi: 10.1111/j.1365-2893.2008.01019.x.

[74] Berenguer M. Systematic review of the treatment of established recurrent hepatitis $\mathrm{C}$ with pegylated interferon in combination with ribavirin. $\mathrm{J}$ Hepatol 2008;49:274-287. doi: 10.1016/j.jhep.2008.05.002.

[75] Levitsky J, Fiel MI, Norvell JP, Wang E, Watt KD, Curry MP, et al. Risk for immune-mediated graft dysfunction in liver transplant recipients with recurrent $\mathrm{HCV}$ infection treated with pegylated interferon. Gastroenterology 2012;142:1132-1139. doi: 10.1053/j.gastro.2012.01.030.

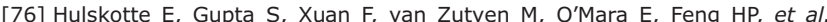
Pharmacokinetic interaction between the hepatitis $C$ virus protease inhibitor boceprevir and cyclosporine and tacrolimus in healthy volunteers. Hepatology 2012;56:1622-1630. doi: 10.1002/hep.25831.

[77] Garg V, van Heeswijk R, Lee JE, Alves K, Nadkarni P, Luo X. Effect of telaprevir on the pharmacokinetics of cyclosporine and tacrolimus. Hepatology 2011; 54:20-27. doi: 10.1002/hep.24443.

[78] Forns X, Samuel D, Mutimer D, Fagiouli S, Navasa M, Agarwal K, et al. Interim SVR12 results from the telaprevir phase 3B REPLACE Study in TreatmentNaïve Stable Liver Transplant Patients with Genotype $1 \mathrm{HCV}$ Infection. ] Hepatology 2014;60 (Suppl):S481-482.

[79] Burton JR Jr, O'Leary JG, Verna EC, Saxena V, Dodge JL, Stravitz RT, et al. A US multicenter study of hepatitis $C$ treatment of liver transplant recipients with protease-inhibitor triple therapy. J Hepatol 2014 May 5. doi: 10.1016/ j.jhep.2014.04.037.

[80] Coilly A, Roche B, Dumortier J, Leroy V, Botta-Fridlund D, Radenne S, et al. Safety and efficacy of protease inhibitors to treat hepatitis $C$ after liver transplantation: a multicenter experience. J Hepatol 2014;60:78-86. doi: 10.1016/j.jhep.2013.08.018.

[81] Charlton M, Gane E, Manns M, Brown R, Curry M, Kwo P, et al. Sofosbuvir and Ribavirin for the Treatment of Established Recurrent Hepatitis C Infection After Liver Transplantation: Preliminary Results of a Prospective, Multicenter Study. AASLD; Nov 1-4, 2013; Wash DC, USA. Abstract LB-2.

[82] Forns $X$, Prieto $M$, Charlton M, McHutchison J, Symonds W, Brainard D, et al. Sofosbuvir compassionate use program for patients with severe recurrent hepatitis $C$ including fibrosing cholestatic hepatitis following liver transplantation. The 49th Annual Meeting of the European Association for the Study of the Liver; April 9-13, 2014; London, England. Abstract O-138.

[83] Jacobson I, Rodriguez-Torres M, Younossi Z, Corregidor A, Sulkowski M, De Jesus $E$, et al. SVR results of a once-daily regimen of simeprevir (TMC435) plus sofosbuvir (GS-7977) with or without ribavirin in cirrhotic and noncirrhotic HCV genotype 1 treatment-naïve and prior null responder patients: the COSMOS study. Hepatology 2013;58 (Suppl 1):1379A.

[84] Lawitz E, Ghalib R, Rodriguez-Torres M, Younossi Z, Corregidor A, Sulkowsk $M$, et al. Simeprevir plus sofosbuvir with/without ribavirin in HCV genotype-1 prior null-responder/treatment-naive patients (COSMOS study): primary endpoint (SVR12) results in patients with METAVIR F3-4 (Cohort 2). The 49th Annual Meeting of the European Association for the Study of the Liver; April 9-13, 2014; London, England. Abstract 165.

[85] Afdhal N, Reddy KR, Nelson DR, Lawitz E, Gordon SC, Schiff E, et al. Ledipasvir and sofosbuvir for previously treated HCV genotype 1 infection. N Engl J Med 2014;370:1483-1493. doi: 10.1056/NEJMoa1316366.

[86] Kwo P, Mantry P, Coakley E, Te H, Vargas H, Brown Jr H, et al. Results of the Phase 2 STUDY M12-999: Interferon Free Regimen of ABT-450/r/ABT-267 + ABT-333 + Ribavirin in Liver Transplant Recipients with Recurrent HCV Genotype 1 Infection. The 49th Annual Meeting of the European Association for the Study of the Liver; April 9-13, 2014; London, England. Abstract 0-114.

[87] http://www.hcvguidelines.org/, accessed May 2014. 